\title{
Chemical content and estimated sources of fine fraction of particulate matter collected in Krakow
}

\author{
Lucyna Samek $^{1} \cdot$ Zdzislaw Stegowski $^{1} \cdot$ Leszek Furman $^{1} \cdot$ Joanna Fiedor $^{1}$
}

Received: 18 January 2016 / Accepted: 28 April 2016 / Published online: 10 May 2016

(C) The Author(s) 2016. This article is published with open access at Springerlink.com

\begin{abstract}
The monitored level of pollution remains high in Krakow, Poland. Alerts regarding increased levels of pollution, which advise asthmatics, the elderly, and children to limit their exposure to open air, continue to be issued on numerous days. In this work, seasonal variations in PM2.5 (particulate matter containing particles with aerodynamic diameter no higher than $2.5 \mu \mathrm{m}$ ) concentrations are shown. An increasing trend is reported, which is enhanced during the colder seasons. The mean PM2.5 concentrations in Krakow exceeded the target value of $25 \mu \mathrm{g} / \mathrm{m}^{3}$ specified for 2015 in the spring, autumn, and winter seasons. For this reason, particulate matter pollution is of special concern. Elemental concentrations as well as the presence of black carbon (BC) and black smoke (BS) in PM2.5 samples were determined. Seasonal variations of $\mathrm{Cl}, \mathrm{K}, \mathrm{Ca}, \mathrm{Ti}, \mathrm{Mn}$, $\mathrm{Fe}, \mathrm{Cu}, \mathrm{Zn}, \mathrm{Br}, \mathrm{Rb}, \mathrm{Sr}$, and $\mathrm{Pb}$ concentrations were observed whereas $\mathrm{V}, \mathrm{Cr}, \mathrm{Ni}, \mathrm{BC}$, and $\mathrm{BS}$ concentrations did not significantly change with the time of year. Seven factors were identified by the positive matrix factorization (PMF) technique, and one was non-identified. They were attributed to the following sources of pollution: steel industry, traffic (diesel exhaust), traffic (gasoline exhaust, brake wear), road dust, construction dust, combustion (biomass, coal), and non-ferrous metallurgical industry. The last, non-identified source, could be
\end{abstract}

Lucyna Samek

Lucyna.Samek@ fis.agh.edu.pl

1 Faculty of Physics and Applied Computer Science, AGH University of Science and Technology, 30 Mickiewicza Ave., 30-059 Krakow, Poland attributed to secondary aerosols. It is worth to mention that combustion shows significant seasonal variations with a high impact in winter. The reported results of the completed studies may significantly aid in solving air quality issues in the city by highlighting major sources of air pollution.

Keywords Particulate matter · Energy dispersive x-ray spectrometry $\cdot$ Positive matrix factorization

\section{Introduction}

According to European Directives, the concentrations of $\mathrm{NO}_{\mathrm{x}}, \mathrm{CO}_{2}$, and particulate matter significantly exceed the specified limit values (Ostro et al. 2015; Kim et al. 2004; Lim et al. 2011). Increased levels of air pollution can negatively affect human health, especially prolonged exposure to polluted air may cause respiratory and cardiovascular diseases. The overall mortality and morbidity can also be influenced (Brunekreef and Holgate 2002; Anenberg et al. 2010; Samek 2016). A component of air pollution which is given special attention is $\mathrm{PM}_{2.5}-\mathrm{a}$ number of research groups has reported major and trace elements concentrations in $\mathrm{PM}_{2.5}$ (Cuccia et al. 2013; Yu et al. 2013; Moreno et al. 2006; Samek et al. 2015, 2016; Zhang et al. 2015, Terrouche et al. 2016). Due to the fact that elemental composition is determined by unique factors, its determination may lead to the identification of sources of air pollution. Properly identified sources can then improve the efforts to minimize pollution levels in different cities. Since chemical content of air particulate matter determines its toxicity, receptor models are used for source identification and apportionment based on the concentrations of chemical species in $\mathrm{PM}_{2.5}$ (Mazzei et al. 
2008; Laupsa et al. 2009; Querol et al. 2007; Masiol et al. 2014).

Krakow is located in a valley in Southern Poland. The city is characterized by a high level of particulate matter pollution. Steel and non-ferrous metallurgical industries are located within the city. Other sources of PM pollution are also present, they include traffic (from diesel or gasoline exhausts), brake, and tire wear. Additionally, the air in Krakow is influenced by long-range transport of aerosols (e.g., secondary aerosols) (Samek 2012; Samek et al. In press). These studies identified potential sources. However, the time series of source contributions was not identified in these studies due to limited number of samples, short duration of sampling, or discontinuous sampling. A long period of daily $\mathrm{PM}_{2.5}$ data is needed in order to obtain a precise source identification. The present study was designed to fill this gap.

The aim of this work is to present results of chemical analyses of $\mathrm{PM}_{2.5}$ samples collected during a 1-year period $(2014 / 2015)$ in an urban area of Krakow. Major and trace element, black carbon, and black smoke concentrations as well as seasonal variations were determined. Additionally, source identification was performed and seasonal variations of likely $\mathrm{PM}_{2.5}$ sources were unveiled. The application of a full year continuous data could not only improve the efficiency of positive matrix factorization (PMF) analysis, but also help to perform the time series analysis of various sources.

In this work, PMF is applied as described by Paatero (Paatero 1997). The sources are classified as natural or anthropogenic. Natural sources include suspended soil and road dust, sea salt, forest fires as well as long-range transported dust (Marconi et al. 2014). The following are a part of anthropogenic sources: industry, traffic, combustion of biomass, or coal for residential heating.

\section{Experimental}

\section{Sampling}

Samples were collected by the Voivodship Inspectorate of Environmental Protection in Krakow. The site selected for the study was an urban area of Krakow, specifically, the southeastern part of the city (district Kurdwanow). The major local sources of pollution are municipal emissions, industry, and traffic. Traffic in the city is dense with frequent traffic jams. Factories are located at a distance of about $10 \mathrm{~km}$ from the sampling site. Additionally, a power plant is located in the southern area of the city. The Upper Silesian industry area can be found approximately $80 \mathrm{~km}$ to the west from Krakow. Moreover, the zinc industry is situated about $50 \mathrm{~km}$ to the north of the city.
Twenty-four-hour $\mathrm{PM}_{2.5}$ fraction samples were collected between February 1, 2014 and January 31, 2015 with the use of a low volume sampler with a flow rate of $2.3 \mathrm{~m}^{3} / \mathrm{h}$. Quartz $(46.2 \mathrm{~mm})$ filters were used as a support. Overall, 194 samples were collected during the entire year.

\section{Chemical analysis}

$\mathrm{PM}_{2.5}$ concentrations were determined by the Voivodship Inspectorate of Environmental Protection in Krakow. Concentrations of the following elements were quantified: $\mathrm{Cl}, \mathrm{K}, \mathrm{Ca}, \mathrm{Ti}, \mathrm{V}, \mathrm{Cr}, \mathrm{Mn}, \mathrm{Fe}, \mathrm{Ni}, \mathrm{Cu}, \mathrm{Zn}, \mathrm{Br}, \mathrm{Sr}, \mathrm{Rb}$, and $\mathrm{Pb}$. Samples of $\mathrm{PM}_{2.5}$ were analyzed with the use of a multifunctional energy dispersive X-ray fluorescence spectrometer as thin samples. The instrument is a microbeam X-ray fluorescence spectrometer with capillary Xray optics, a broad X-ray beam from a molybdenum secondary target for XRF analysis of bulk samples, and a total reflection X-ray technique. The molybdenum tube is the source of X-rays. The tube has the power of $2 \mathrm{~kW}$. The excited X-rays were detected by a $\mathrm{Si}(\mathrm{Li}) \mathrm{de}-$ tector with resolution of $170 \mathrm{eV}$ at an energy of $5.9 \mathrm{keV}$. Data collection was completed using the Canberra system. The measurements were carried out under the following conditions: voltage of $55 \mathrm{kV}$, current of $30 \mathrm{~mA}$, measurement time of 10,000 s, and under atmospheric air. In order to calculate the concentrations of different elements in the filters, the spectrometer was calibrated using thin-film standards (Micromatter, USA). The calibration was verified by the analysis of the NIST Standard Reference Material (2783-Air particulate matter on filter media). Table 1 presents certified and measured elemental concentrations of the NIST Standard Reference Material. The XRF spectra were quantitatively analyzed with the use of the QXAS package (Vekemans et al. 1994).

Table 1 Measured and certified concentrations of elements in NIST SRM2783

\begin{tabular}{lll}
\hline Element & Measured values (ng) & Certified values (ng) \\
\hline $\mathrm{K}$ & $6011 \pm 4500$ & $5280 \pm 520$ \\
$\mathrm{Ca}$ & $18,780 \pm 3500$ & $13,200 \pm 1700$ \\
$\mathrm{Ti}$ & $1384 \pm 130$ & $1490 \pm 240$ \\
$\mathrm{Cr}$ & $115 \pm 67$ & $135 \pm 25$ \\
$\mathrm{Mn}$ & $319 \pm 66$ & $320 \pm 12$ \\
$\mathrm{Fe}$ & $27,111 \pm 678$ & $26,500 \pm 1600$ \\
$\mathrm{Cu}$ & $398 \pm 25$ & $404 \pm 42$ \\
$\mathrm{Zn}$ & $2077 \pm 63$ & $1790 \pm 130$ \\
$\mathrm{~Pb}$ & $244 \pm 25$ & $317 \pm 54$ \\
\hline
\end{tabular}


Table 2 Concentrations of chemical species in Krakow during different seasons of the year (concentrations of $\mathrm{PM}_{2.5}, \mathrm{BC}$, BS are in $\mu \mathrm{g} / \mathrm{m}^{3}$, and rest of species in $\mathrm{ng} / \mathrm{m}^{3}$ )

\begin{tabular}{lllll}
\hline Element & Spring & Summer & Autumn & Winter \\
\hline $\mathrm{PM}_{2.5}$ & $31 \pm 23$ & $12.7 \pm 4.6$ & $30 \pm 21$ & $57 \pm 39$ \\
$\mathrm{Cl}$ & $674 \pm 1408$ & $<\mathrm{DL}$ & $361 \pm 704$ & $3609 \pm 3548$ \\
$\mathrm{~K}$ & $255 \pm 411$ & $17 \pm 36$ & $49 \pm 115$ & $507 \pm 537$ \\
$\mathrm{Ca}$ & $264 \pm 380$ & $59 \pm 144$ & $36 \pm 72$ & $169 \pm 221$ \\
$\mathrm{Ti}$ & $13 \pm 13$ & $8.4 \pm 7.5$ & $6.8 \pm 5.3$ & $7.7 \pm 7.3$ \\
$\mathrm{~V}$ & $1.7 \pm 1.3$ & $1.7 \pm 1.6$ & $1.7 \pm 1.3$ & $1.6 \pm 1.3$ \\
$\mathrm{Cr}$ & $3.8 \pm 2.7$ & $3 \pm 2$ & $6.5 \pm 5.1$ & $6.0 \pm 4.4$ \\
$\mathrm{Mn}$ & $5.9 \pm 4.5$ & $3.5 \pm 2.4$ & $5.1 \pm 4.7$ & $7.7 \pm 8.7$ \\
$\mathrm{Fe}$ & $261 \pm 217$ & $102 \pm 90$ & $195 \pm 139$ & $267 \pm 219$ \\
$\mathrm{Ni}$ & $1.9 \pm 1.0$ & $1.7 \pm 1.0$ & $0.9 \pm 0.8$ & $0.6 \pm 0.2$ \\
$\mathrm{Cu}$ & $8.5 \pm 9.1$ & $2.9 \pm 2.2$ & $5.5 \pm 4.6$ & $12 \pm 11$ \\
$\mathrm{Zn}$ & $67 \pm 52$ & $18 \pm 10$ & $59 \pm 55$ & $118 \pm 89$ \\
$\mathrm{Br}$ & $11 \pm 9$ & $3.3 \pm 1.5$ & $9.8 \pm 8.5$ & $25 \pm 17$ \\
$\mathrm{Rb}$ & $1.5 \pm 1.0$ & $0.9 \pm 0.5$ & $1.4 \pm 1.1$ & $2.3 \pm 1.3$ \\
$\mathrm{Sr}$ & $1.9 \pm 1.1$ & $1.7 \pm 1.1$ & $1.1 \pm 0.8$ & $0.9 \pm 0.9$ \\
$\mathrm{~Pb}$ & $20 \pm 17$ & $5.4 \pm 3.8$ & $18 \pm 16$ & $43 \pm 32$ \\
$\mathrm{BC}$ & $2.4 \pm 1.3$ & $2.7 \pm 1.2$ & $2.8 \pm 1.2$ & $2.6 \pm 1.3$ \\
$\mathrm{BS}$ & $10.4 \pm 6.5$ & $12.0 \pm 5.6$ & $12.6 \pm 6.2$ & $11.4 \pm 6.1$ \\
\hline $\mathrm{St}$ & & & &
\end{tabular}

St.dev. - variability of concentrations during the measured period

The presence of black carbon (BC) and black smoke (BS) was determined by UV-VIS spectroscopy. Spectroscopic measurements were performed using a Varian Cary 50-Bio UVVIS spectrophotometer (Agilent). Transmittance was recorded at the $880 \mathrm{~nm}$ wavelength, triplicate for each sample. Additionally, transmission spectra were collected in the range of 200-1000 nm. All measurements were carried out in reference to air. Concentrations of BC and BS were calculated according to formulas listed by Quincey P. (Quincey 2007).

\section{Statistical analysis}

Source apportionment analysis was carried out using the positive matrix factorization receptor model (version PMF5.0) developed by the United States Environmental Protection Agency (US EPA).

PMF requires two inputs to run, namely concentration and its uncertainty. In this work, if the concentration was less than or equal to the detection limit (DL) provided, the uncertainty was calculated as five sixths DL and the concentration as one half DL (Pollisar 1998). Missing data was substituted with median values, and the corresponding uncertainties were replaced by four times the median values. $\mathrm{PM}_{2.5}$ concentration was included as a total variable, and all the species were characterized as "strong," "weak," or "bad" depending on the signal to noise ratio.

The input data for the PMF model included 194 samples with 18 species (concentration of $\mathrm{PM}_{2.5}, 15$ elements, $\mathrm{BC}$ and BS). Concentrations of three elements, $\mathrm{V}, \mathrm{Sr}$, and $\mathrm{Rb}$, were excluded because many of the corresponding values were below the detection limit and they were characterized by low signal to noise values.

\section{Results and discussion}

Table 2 shows concentrations of $\mathrm{PM}_{2.5}, \mathrm{BC}$, BS, and major and trace elements in $\mathrm{PM}_{2.5}$ during different seasons of the 2014/2015 period. The lowest concentration of $\mathrm{PM}_{2.5}$ was observed in the summer. It was significantly below the target value specified by the EU Directive (2008). Concentrations reported during spring and autumn were slightly higher than the target value whereas those observed in the winter were as high as twice the target value. In Poland, in the Regulation of the Minister of the Environment (2012), the limit value of

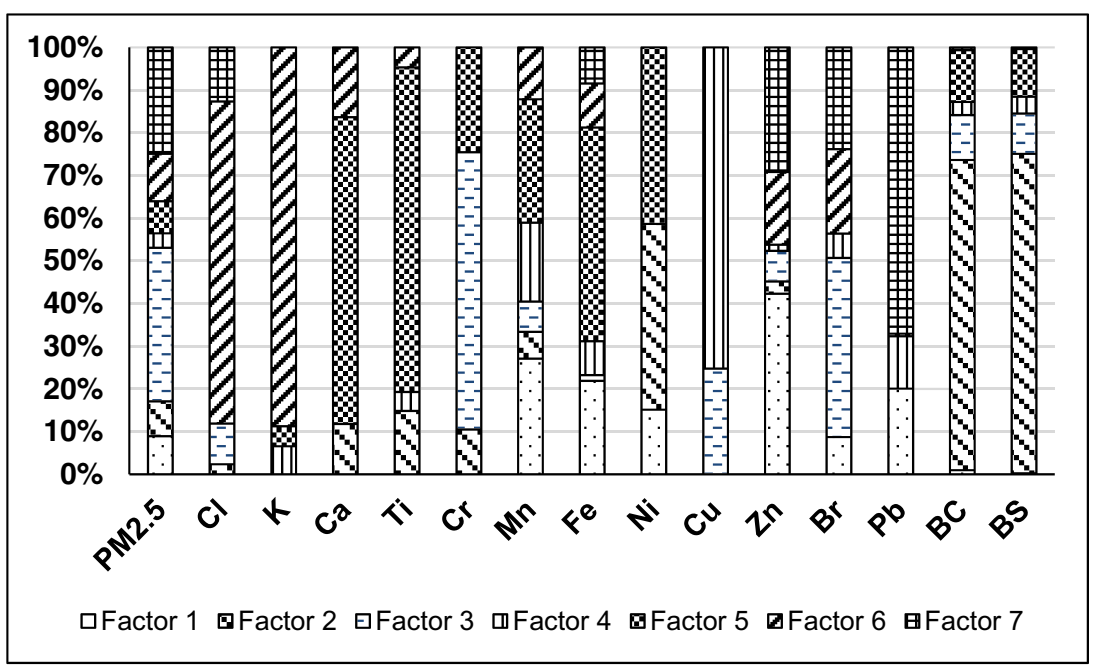

Fig. 1 Factor profiles of fine particulate matter. For attributions to factors, see Table 3 
Fig. 2 Source contributions in micrograms per cubic meter. For attributions to factors, see Table 3

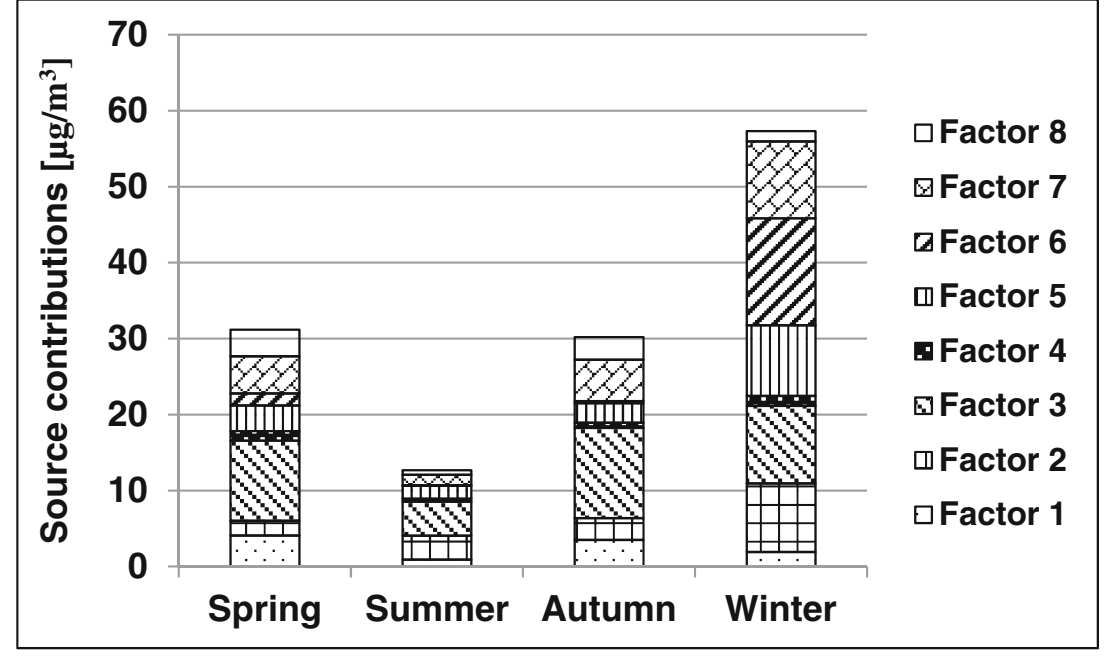

$\mathrm{PM}_{2.5}$ concentration was $25 \mu \mathrm{g} / \mathrm{m}^{3}$ - the same as target value to be met in 2015 (phase I) as well as target value equal to $20 \mu \mathrm{g} / \mathrm{m}^{3}$ to be met in 2020 (phase II). Strong seasonal variations were noted for concentrations of $\mathrm{Cl}, \mathrm{K}, \mathrm{Br}, \mathrm{Pb}, \mathrm{Cu}$, and $\mathrm{Zn}$. $\mathrm{Cl}$ and $\mathrm{K}$ can originate from combustion of coal and/or biomass. Ratios of $\mathrm{Cu}$ to $\mathrm{Zn}$ were in the range of $0.09-0.16$ depending on the season. A $\mathrm{Cu}$ to $\mathrm{Zn}$ ratio equal to 0.3 indicative of traffic was reported by (Mazzei et al. 2008). Ratios of $\mathrm{Cu}$ to $\mathrm{Pb}$ were 0.43 and 0.46 in spring and summer, respectively. A higher value of 0.69 was reported in the summer, and a low number of 0.28 was found in the winter. These elements present in ratios in the range of 2.3-3.0 were identified as indicators of traffic by (Mazzei et al. 2008). These results suggest that a source of $\mathrm{Pb}$ other than traffic also exists. The $\mathrm{Zn}$ to $\mathrm{Pb}$ ratio in winter was equal to 2.74 and in other seasons of the year it was in the range 3.28-3.35. The ratio of $\mathrm{Pb}$ to $\mathrm{Br}$ was equal to $1.64-1.85$, and it remained constant during all seasons of the year. Concentrations of $\mathrm{Ca}$ and $\mathrm{Ti}$ were the highest in spring and the lowest in autumn. These elements can be related to construction dust created at prevalent construction sites in Krakow. Other elements such as $\mathrm{V}$ were present in constant concentrations during the year. Ni concentrations in spring and summer were twice as large as those reported in winter and autumn. $\mathrm{V}$ and $\mathrm{Ni}$ are indicators of traffic. Black carbon and black smoke had the highest values in autumn and were higher than those found in Ghent and Amsterdam but were similar to those noted in Barcelona. During the remaining seasons, the values were comparable between the various cities. Based on the assumption that black carbon is a tracer for primary emissions, mostly derived from traffic, these results suggest that the influence of traffic on air pollution is higher in Krakow than in Amsterdam and Ghent and on a similar level as in Barcelona (Viana et al. 2007).

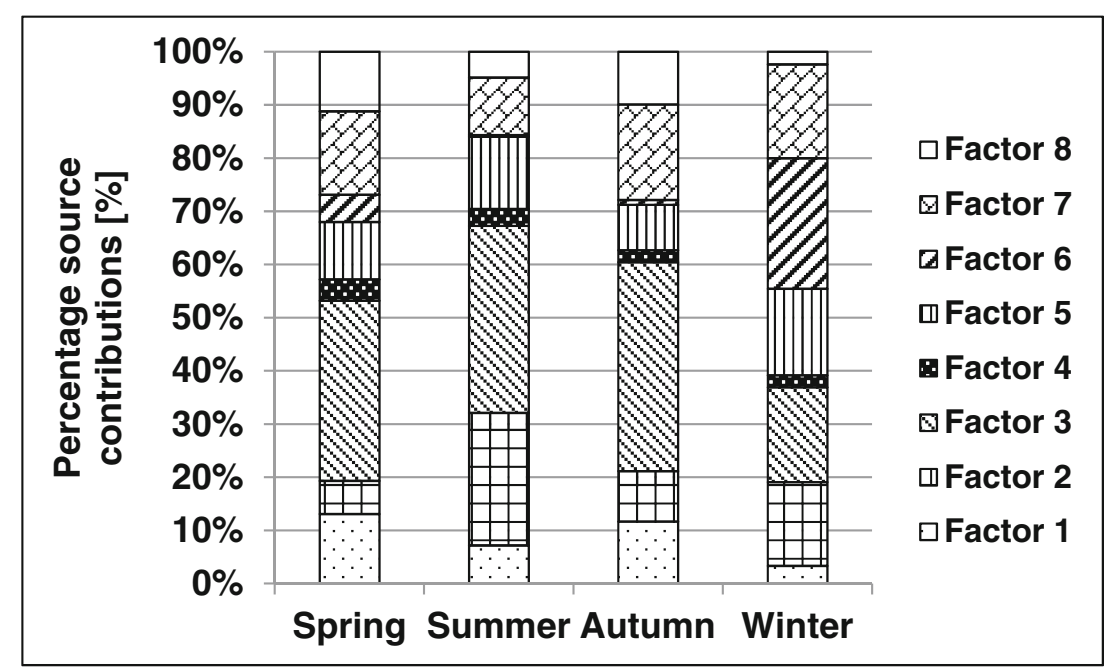

Fig. 3 Percentage source contributions 
Table 3 Factors with attributed sources and their contribution to PM mass concentrations

\begin{tabular}{lllllll}
\hline Factor & Attributed source & Indicators & \multicolumn{3}{l}{ Source contributions (\%) } & \\
\cline { 4 - 7 } number & & & Spring & Summer & Autumn & Winter \\
\hline Factor 1 & Steel industry & $\mathrm{Mn}, \mathrm{Fe}, \mathrm{Zn}, \mathrm{Br}, \mathrm{Pb}$ & 13 & 11.7 & 7 & 3.3 \\
Factor 2 & Traffic (diesel exhaust) & $\mathrm{Ni}, \mathrm{BC}, \mathrm{BS}$ & 6.2 & 24.9 & 9.5 & 15.7 \\
Factor 3 & Traffic (gasoline exhaust) & $\mathrm{Cr}, \mathrm{Cu}, \mathrm{Br}, \mathrm{BC}, \mathrm{BS}$ & 33.7 & 35 & 39 & 17.8 \\
Factor 4 & Road dust & $\mathrm{Cu}$ & 4.0 & 3.2 & 2.2 & 2.3 \\
Factor 5 & $\begin{array}{c}\text { Construction dust and/or soil } \\
\text { dust }\end{array}$ & $\mathrm{Ca}, \mathrm{Ti}, \mathrm{Cr}, \mathrm{Mn}, \mathrm{Fe}$, & 10.8 & 13 & 8.5 & 10 \\
Factor 6 & $\begin{array}{c}\text { Combustion coal and/or } \\
\text { biomass }\end{array}$ & $\mathrm{Cl}, \mathrm{Ni}$, & 5 & 0.3 & 0.9 & 24.6 \\
Factor 7 & $\begin{array}{c}\text { Non-ferrous metallurgical } \\
\text { industry }\end{array}$ & $\mathrm{Zn}, \mathrm{Br}, \mathrm{Pb}$ & 15.7 & 11 & 18 & 18 \\
Factor 8 & Non-identified source & & 11.2 & 5 & 9.9 & 2.4 \\
\hline
\end{tabular}

Figure 1 presents the factor profiles. Figure 2 and Fig. 3 show source contributions in microgams per cubic meter and percent, respectively. A positive matrix factorization model was used for source identification and apportionment. Seven factors were established, and one was non-identified. Table 3 shows condensed data of contributions of each source and factors with attributable indicators. Mazzei et al. (2008) found indicators of the steel industry as $\mathrm{Fe}, \mathrm{Mn}$ as well as traffic $\mathrm{Cu}, \mathrm{Zn}$, and $\mathrm{Pb}$. Indicators of the non-ferrous metallurgical industry can be $\mathrm{Cu}$, $\mathrm{Zn}, \mathrm{Pb}, \mathrm{As}, \mathrm{Cr}, \mathrm{Ni}$, and $\mathrm{Co}$ while burning of oil $\mathrm{Ba}, \mathrm{Co}, \mathrm{Ni}, \mathrm{V}, \mathrm{Cr}$, and Mn (Kabata-Pendias, Pendias 1999). Jedynska et al (Jedynska et al. 2014) reported that EC can be an indicator of diesel emissions. Yu et al. (2013) published that biomass burning indicator was $\mathrm{K}$ as well as fossil fuel combustion indicators were $\mathrm{Cl}, \mathrm{V}, \mathrm{Ni}, \mathrm{As}$, and $\mathrm{Pb}$. Confirmation of this finding also is the paper of Viana (Viana et al. 2008).

In a previous study (Samek et al. In press), fine fraction principal component analysis (PCA) and multilinear regression analysis (MLRA) were performed. The contribution of municipal emissions combined with industry was estimated to be $49.2 \%$ during winter, that of traffic was at $37.8 \%$. In the present study, the contribution of traffic in winter was similar at $36.5 \%(15.7 \%$ diesel exhaust, $17.8 \%$ gasoline exhaust, $3 \%$ road dust) while that of combustion was equal to $25 \%$; the steel industry contributed $3.4 \%$ and the non-ferrous metallurgical industry added $18 \%$. The previously mentioned study (Samek et al. In press) reported a mean contribution of traffic equal to $53 \%$ (40-60\%) in summer. In this study, it was found to be equal to $62.9 \%$ ( $24.9 \%$ diesel exhaust, $35 \%$ gasoline exhaust, $3 \%$ road dust). The cited work stated the contribution of industry in summer to be equal to $18 \%$ (in the range of 5-40\%). In this study, the corresponding contribution was at $20.3 \%$ (3.3\% steel industry, $17 \%$ non-ferrous metallurgical industry). PMF results were consistent with the previously completed research. This research provided an increased number of factors indicated as pollutants as well as a more complete analysis than previous ones. This study complements previous investigations performed during a more limited time period ( 1 month in summer and one in winter) by delivering new valuable information.

\section{Conclusions}

Chemical characterization of $\mathrm{PM}_{2.5}$ fraction collected in Krakow was reported. Certain elements such as $\mathrm{Cl}, \mathrm{K}, \mathrm{Br}, \mathrm{Pb}, \mathrm{Cu}$, and $\mathrm{Zn}$ show strong seasonal variations of concentrations whereas others - V, Ni, BC, BS - do not exhibit such deviations. Eight contributing factors were identified, and a single pollution source was attributed to each one. Strong seasonal variations were associated with combustion, with the peak value reported in winter. Contributions of traffic were constant throughout the year. This study is consistent with a previously published work regarding $\mathrm{PM}_{2.5}$. It involved an extended period of time, a larger number of analyzed samples, and, as a result, more detailed information. This data is particularly relevant to the identification of pollution sources in Krakow. However, further analyses need to be performed in order to determine the impact of the described pollution on human health.

Open Access This article is distributed under the terms of the Creative Commons Attribution 4.0 International License (http:// creativecommons.org/licenses/by/4.0/), which permits unrestricted use, distribution, and reproduction in any medium, provided you give appropriate credit to the original author(s) and the source, provide a link to the Creative Commons license, and indicate if changes were made.

\section{References}

Anenberg SC, Horowitz LW, Tong DQ, West JJ (2010) An estimate of the global burden of anthropogenic ozone and fine particulate matter on premature human mortality using atmospheric modeling. Environ Health Persp 118:1189-1195. doi:10.1289/ehp.0901220

Brunekreef B, Holgate ST (2002) Air pollution and health. Lancet 360: $1233-1242$ 
Cuccia E, Massabo D, Ariola V, Bove MC, Fermo P, Piazzalunga A, Prati P (2013) Size-resolved comprehensive characterization of airborne particulate matter. Atmos Environ 67:14-26. doi:10.1016/j. atmosenv.2012.10.045

EU Directive 2008/50/EC of the European Parliament and the Council of 21 May 2008.

Jedynska A, Hoek G, Eeftens M, Cyrys J, Keuken M, Ampe C, Beelen, Cesaroni G, Forastiere F, Cirach M, de Hoogh K, de Nazelle A, Madsen C, Declercq C, Eriksen K,T, Katsouyanni K, Akhlaghi H, M, Lanki T, Meliefste K, Nieuwenhuijsen M, Oldenwening M, Pennanen A, Raaschou-Nielsen O, Brunekreef B, Kooter I, M (2014) Spatial variations of PAH, hopanes/steranes and EC/OC concentrations within and between European study areas. Atmos Environ 87:239-248. doi:10.1016/jatmosenv.2014.01.026

Kabata-Pendias A, Pendias H (1999) Biogeochemistry of trace elements. PWN, Warsaw (In Polish)

Kim JJ, Smorodinsky S, Lipsett M, Singer BC, Hodgson AT, Ostro B (2004) Traffic-related air pollution near busy roads: the East Bay Children's Respiratory Health Study. Am J Resp Crit Care 170:520-526

Laupsa H, Denby B, Larssen S, Schaug J (2009) Source apportionment of particulate matter (PM2.5) in an urban area using dispersion, receptor and inverse modelling. Atmos Environ 43:4733-4744. doi:10. 1016/j.atmosenv.2008.07.010

Lim J, Jeong J, Lee J, Moon J, Chung Y, Kim K (2011) The analysis of PM2.5 and associated elements and their indoor/outdoor pollution status in an urban area. Indoor Air 21:145-155. doi:10.1111/j.16000668.2010.00691.x

Marconi M, Sferlazzo DM, Becagli S, Bommarito C, Calzolai G, Chiari M, Sarra A, Ghedini C, Gómez-Amo JL, Lucarelli F, Meloni D, Monteleone F, Nava S, Pace G, Piacentino S, Rugi F, Severi M, Traversi R, Udisti R (2014) Saharan dust aerosol over the Central Mediterranean Sea: PM10 chemical composition and concentration versus optical columnar measurements. Atmos Chem Phys 14: 2039-2054. doi:10.5194/acp-14-2039-2014

Masiol M, Squizzato S, Rampazzo G, Pavoni B (2014) Source apportionment of PM2.5 at multiple sites in Venice (Italy): spatial variability and the role of weather. Atmos Environ 98:78-88. doi:10.1016/j. atmosenv.2014.08.059

Mazzei F, Alessandro AD, Lucarelli F, Nava S, Prati P, Valli G, Vecchi R (2008) Characterization of particulate matter sources in an urban environment. Sci Total Environ 401:81-89. doi:10.1016/j. scitotenv.2008.03.008

Moreno T, Querol X, Alastuey A, Viana M, Salvador P, de la Campa AS, Artinano B, de la Rosa J, Gibbons W (2006) Variations in atmospheric PM trace metal content in Spanish towns: illustrating the chemical complexity of the inorganic urban aerosol cocktail. Atmos Environ 40: 6791-6803. doi:10.1016/j.atmosenv.2006.05.074

Ostro B, Tobias A, Karanasiou A, Samoli E, Querol X, Rodopoulou S, Basagana X, Eleftheriadis K, Diapouli E, Vratolis S, Jacquemin B, Katssouyanni K, Suner J, Forastiere F, Stafoggia M (2015) The risk of acute exposure to black carbon in southern Europe: results from the MED-PARTICLES project. Occup Environ Med 72:123-129. doi:10.1136/oemed-2014-102184

Paatero P (1997) Least squares formulation of robust nonnegative factor analysis. Atmos Environ 37:23-35. doi:10.1016/S0169-7439(96) 00044-5
Pollisar AV (1998) Atmospheric aerosol over Alaska: 2. Elemental Composition and Sources J Geophys Res 10:19045-19057. doi: 10.1029/98JD01212

Querol X, Viana M, Alastuey A, Amato F, Moreno T, Castillo S, Pey J, de la Rosa J, Sanchez de la Campa S, Artinano B, Salvador P, Garcia Dos Santos S, Fernandez-Patier R, Moreno-Grau S, Negral L, Minguillon MC, Monfort E, Gil JI, Inza A, Ortega LA, Santameria JM, Zabalza J (2007) Source origin of trace elements in PM from regional background, urban and industrial sites of Spain. Atmos Environ 41:7219-7231. doi:10.1016/j.atmosenv.2007.05.022

Quincey P (2007) A relationship between Black Smoke Index and black carbon concentration. Atmos Environ 41:7964-7968. doi:10.1016/j. atmosenv.2007.09.033

Regulation of the Minister of the Environment (2012) on the levels of certain substances in the air 24 August 2012, Dz.U. 1031

Samek L (2012) Source apportionment of the PM10 fraction of particulate matter collected in Krakow, Poland. Nukleonika 57(4):601-606

Samek L, Furman L, Kawik T, Welnogorska K (2015) Application of Xray fluorescence method for elemental analysis of PM2.5 fraction. Nukleonika 60(3):621-626

Samek L (2016) Overall human mortality and morbidity due to exposure to air pollution. Int J Occup Med Env 29: 417-426. doi:10.13075/ ijomeh.1896.00560

Samek L, Gdowik A, Ogarek J, Furman L (2016) Elemental composition and rough source apportionment of fine particulate matter in Krakow, Poland. Environ Prot Eng (in press)

Terrouche A, Ali-Khodja H, Kemmouche A, Bouziane M, Derradji A, Charron A (2016) Identification of sources of atmospheric particular matter and trace metals in Constantine, Algeria. Air Qual Atmos Health 9:69-82. doi:101007/s11869-014-0308-1

Vekemans B, Janssens K, Vincze L, Adams F, Van Espen P (1994) Analysis of X-ray spectra by iterative least squares (AXIL): new developments. X-Ray Spectrom 23:278-285. doi:10.1002/xrs. 1300230609

Viana M, Maenhaut W, ten Brink HM, Chi X, Weijrs E, Querol X, Alastuey A, Mikuska P, Vecela Z (2007) Comparative analysis of organic and elemental carbon concentrations in carbonaceous aerosols in three European cities. Atmos Environ 41:5972-5983. doi:10. 1016/j.atmosenv.2007.03.035

Viana M, Kuhlbusch TAJ, Querol X, Alastuey A, Harrison RM, Hopke PK, Winiwarter W, Vallius m, szidat S, Prevot ASH, Hueglin C, Bloemen H, Wahlin P, Vecchi R, Miranda AI, Kasper-Giebl A, Maenhaut W, Hitzenberger R (2008) Source apportionment of particulate matter in Europe: a review of methods and results. Aerosol Sci 39:827-849. doi:10.1016/j.jaerosci.2008.05.007

Yu L, Wang G, Zhang R, Zhang L, Song Y, Wu B, Li X, An K, Chu J (2013) Characterization and source apportionment of PM2.5 in an urban environment in Beijing. Aerosol Air Qual Res 13:574-583. doi:10.4209/aaqr.2012.07.0192

Zhang N, Han B, He F, Xu J, Niu C, Zhou J, Kong S, Bai Z, Xu $\mathrm{H}$ (2015) Characterization, health risk of heavy metals, and source apportionment of atmospheric $\mathrm{PM}_{2.5}$ to children in summer and winter: an exposure panel study in Tianjin, China. Air Qual Atmos Health 8:347-357. doi:10.1007/ s11869-014-0289-0 